\title{
Regulation of reproductive seasonality in the red deer hind: oestradiol-dependent and -independent influences on the patterns of LH concentrations
}

\author{
L. M. Meikle ${ }^{*}$ and M.W. Fisher ${ }^{\dagger}$ \\ AgResearch, Invermay Agricultural Centre, Private Bag 50034, Mosgiel, New Zealand
}

\begin{abstract}
The control of reproductive seasonality was studied in farmed adult red deer hinds that had been either ovariectomized or ovariectomized and oestradiol-treated (s.c. implants). The breeding season, delineated by progesterone secretion in intact hind herdmates, was characterized by high (mean 0.6 , range $0.1-2.5 \mathrm{ng} \mathrm{ml}^{-1}$ plasma) $\mathrm{LH}$ concentrations in ovariectomized oestradiol-treated hinds. In contrast, during the non-breeding season plasma LH concentrations in these animals were significantly lower (mean 0.1 , range $0-0.9 \mathrm{ng} \mathrm{ml}^{-1}$ plasma). LH secretion in ovariectomized untreated hinds also displayed a marked seasonal pattern, approximately the inverse of daily photoperiod (that is, a winter peak and summer trough). The pituitary $\mathrm{LH}$ response to $10 \mu \mathrm{g}$ exogenous $\mathrm{GnRH}$ was also maximal during the breeding season in ovariectomized (mean 7.4, range $1.2-14.6 \mathrm{ng} \mathrm{ml}^{-1}$ ) and ovariectomized, oestradiol-treated (mean 16.4, range $1.4-32.3 \mathrm{ng} \mathrm{ml}^{-1}$ ) hinds. These results indicate that $\mathrm{LH}$ secretion in the hind is regulated by both steroid-dependent and -independent mechanisms.
\end{abstract}

\section{Introduction}

Our understanding of the mechanisms that control reproductive seasonality in female farm animals has largely been derived from studies in ewes (see Karsch et al., 1984). However, domestication may alter some reproductive parameters, including seasonality (see Setchell, 1992). Thus the underlying physiological mechanisms in sheep may differ from those in other species. For example, throughout seasonal anoestrus, the ovariectomized ewe retains the ability to produce a preovulatory-like LH surge in response to exogenous oestradiol (Land et al., 1976; Howland et al., 1978; Goodman ef al., 1981; Haresign and Friman, 1983), but it has been demonstrated that this response is absent during some stages of anoestrus in ovariectomized red (Meikle and Fisher, 1990) and fallow (Jabbour et al., 1992) deer. Furthermore, there is limited evidence of a marked seasonal pattern of $\mathrm{LH}$ secretion in ovariectomized red (Meikle and Fisher, 1990) and fallow (G. W. Asher, unpublished data) deer. These patterns are not as clearly evident in ovariectomized ewes (Legan et al., 1977; Goodman et al., 1982; Webster and Haresign, 1983; Robinson et al., 1985). Although there are some important breed differences in both the negative and positive effects of oestradiol on LH secretion during anoestrus in ewes (Land et al., 1976; McNeilly et al., 1985; Thomas et al., 1988), Karsch et al. (1984) suggested that seasonal anoestrus in ewes is a relatively uniform physiological state. In contrast, in Père David's hinds pituitary LH responsiveness to $\mathrm{GnRH}$ and its efficacy in inducing ovarian activity vary

*Present address: Landcare, P.O. Box 69, Lincoln, Canterbury, New Zealand. ${ }^{\dagger}$ Correspondence.

Received 30 June 1995 significantly with season (Curlewis et al., 1991; McLeod et al., 1991).

In ewes, reproductive seasonality is related to a change in the sensitivity of LH secretion to the negative feedback action of oestradiol and this is concomitant with the onset and cessation of the breeding season (Legan et al, 1977; Karsch et al., 1984). However, the possible contribution of steroidindependent mechanisms to the control of reproductive seasonality is not well understood.

The present study was undertaken to test the hypothesis that in ovariectomized red deer hinds, the seasonal patterns of $\mathrm{LH}$ concentrations are indicative of both steroid-dependent and -independent neuroendocrine control mechanisms. Furthermore, the possible contribution of pituitary responsiveness to seasonal LH concentrations was assessed with exogenous $\mathrm{GnRH}$.

\section{Materials and Methods}

\section{Experimental summary}

The experiment used 24 adult, farmed red deer (Cervus elaphus) hinds, allocated to the following treatment groups (eight per group): (1) ovariectomized; (2) ovariectomized and treated with oestradiol administered via subcutaneous implants, and (3) intact hinds. In sheep, gonadotrophin secretion in ovariectomized animals is influenced by time from ovariectomy (Montgomery et al., 1985; Joseph et al., 1992), as well as by season (Goodman et al., 1982; Robinson et al., 1985); therefore, hinds with two different histories of ovarian removal were used. Blood samples were collected once a week over the 
following 15 months (February 1990 to April 1991) and plasma concentrations of LH determined. In addition, the pituitary LH responsiveness to exogenous $\mathrm{GnRH}$ was assessed every 4 weeks, while the timing and duration of the breeding season in intact herd mates was determined by monitoring ovarian progesterone secretion.

\section{Animal management, ovariectomy and oestradiol treatment}

The hinds were run together as a single group, outdoors (latitude $45^{\circ} 53^{\prime} \mathrm{S}$ ) under normal farm management (except that access to stags was denied) on predominantly ryegrass-white clover pasture, supplemented with meadow hay in winter. At the beginning of the experiment mean ( \pm SEM) ages and masses were $12 \pm 0.4$ years and $114 \pm 2.2 \mathrm{~kg}$, respectively. Ovariectomies were performed via midline laparotomy under general anaesthesia induced i.v. with $1.5 \mathrm{mg}$ fentanyl citrate and $12 \mathrm{mg}$ azaperone (Fentaz: Smith, Kline and French (NZ) Ltd, Auckland) and $77 \mathrm{mg}$ xyaline hydrochloride (Rompun: Bayer NZ Ltd, Petone) and reversed i.v. with $25 \mathrm{mg}$ yohimbine (Mackintosh and Van Reenen, 1984) and $0.2 \mathrm{mg}$ naloxone hydrochloride (Narcan: Endo Laboratories, Artarmon, NSW). Half of the ovariectomized hinds had undergone ovariectomy 2.3 years earlier (May, 1987); these animals had previously been exposed for short periods to progestagens, oestrogen or ACTH treatment (see Jopson et al., 1990; Meikle and Fisher, 1990). The other half underwent ovariectomy at the beginning of the experiment (February, 1990). Silastic implants were prepared from $0.335 \mathrm{~cm}$ inner $\times 0.465 \mathrm{~cm}$ outer diameter silastic tubing (Dow Corning Corp., Midland, MI) $5 \mathrm{~cm}$ in length (of which $0.5 \mathrm{~cm}$ was plugged at each end) containing oestradiol (Sigma Chemical Co., St Louis, MO) as described by Karsch et al. (1973). Ovariectomized hinds that did not receive oestradiol treatment received empty implants. Implants were soaked separately in water overnight, and were immersed in $70 \%$ ethanol for at least $30 \mathrm{~min}$ before insertion. Implants were inserted s.c. into the inguinal region under general anaesthesia, on 27 February 1990 (long-term ovariectomized hinds) or during ovariectomy (short-term ovariectomized animals) on 20 February 1990.

\section{Blood sampling}

Blood samples $(10 \mathrm{ml})$ were taken by jugular venepuncture, with the hinds physically restrained in a compressed air operated deer crush. Blood was collected into heparinized tubes and the plasma removed and stored at $-20^{\circ} \mathrm{C}$ until analysed. Blood samples were taken once a week from all hinds for the duration of the experiment (22 February 1990 to 24 April 1991) and twice a week from entire hinds at about the expected time of the breeding season (March to November). In addition, at intervals of approximately 4 weeks, all animals were treated with GnRH (10 $\mu$ g; Sigma Chemical Co.; made up at the start of the study and frozen in a concentrated form) administered i.v. in saline, immediately after sampling and a further sample was taken 15 min later. This limited sampling protocol was used because of the relatively intractable nature of some farmed animals and was considered appropriate since other studies have revealed that after $\mathrm{GnRH}$ treatment, $\mathrm{LH}$ concentrations peak at 15 min (red hinds: M. W. Fisher and B. J. McLeod, unpublished data; Père David's hinds: Curlewis et al., 1991).

\section{Hormone analyses}

Plasma LH concentrations were measured using a heterologous double-antibody radioimmunoassay developed in our laboratory. The antiserum (R2), raised in a rabbit against highly purified ovine LH (NIAMDD-oLH-24), was used at an initial dilution of 1:60000. The antiserum exhibited low (<1\%) crossreactivity with ovine and cervine growth hormone and bovine thyroid stimulating hormone and little reactivity $(<0.1 \%)$ with ovine FSH or ovine prolactin. The reference preparation and iodinated tracer were the highly purified ovine LH CY1085 (biopotency $3.45 \times \mathrm{NIH}-\mathrm{LH}-\mathrm{S} 1$ ). Standards were made up in $0.1 \%(w / v)$ BSA phosphate buffer to which $100 \mu \mathrm{l}$ of cervine plasma containing low LH (obtained from medroxyprogesterone acetate-treated hinds; Sigma Chemical Co.) was added. Interassay coefficients of variation for plasma pools containing $0.2,1.5$ and $4.5 \mathrm{ng} \mathrm{ml}^{-1}$ were $16.6 \%, 6.7 \%$ and $4.6 \%$, respectively. The intra-assay coefficient of variation calculated on 30 duplicate pairs per assay $(n=6)$ was $9.1 \%$. The limit of assay sensitivity, defined as the apparent concentration at two standard deviations above the zero standard, averaged $0.05 \mathrm{ng} \mathrm{ml}^{-1}$. Parallelism was demonstrated by serial dilutions of hind plasma in assay buffer. Progesterone concentrations were determined, by solid phase ${ }^{125} \mathrm{I}$ radioimmunoassay (Diagnostic Products Corporation, Los Angeles, CA) as described by Jopson et al. (1990). All samples were completed within one assay and the coefficient of variation on a plasma pool containing $3.50 \mathrm{ng} \mathrm{ml}^{-1}$ measured 18 times was $13.4 \%$. The limit of assay sensitivity was $0.08 \mathrm{ng} \mathrm{ml}^{-1}$.

\section{Statistical analyses}

The onset of the breeding season for an individual hind was defined as the date when plasma progesterone concentrations first exceeded $0.5 \mathrm{ng} \mathrm{ml}^{-1}$ and remained above that value for at least 7 days. The end of the breeding season was determined as the last date on which progesterone concentrations fell, and remained below $0.5 \mathrm{ng} \mathrm{ml}^{-1}$ for at least 7 days. Furthermore, there had to be evidence of a regular cyclic pattern (approximately 17-21 day ovarian cycles) in individual hinds.

The variances were equalized by log transforming $\mathrm{LH}$ results and the mean concentrations for breeding and anoestrous season were analysed by analysis of variance, fitting terms for oestradiol treatment, history of ovarian removal (long-term or short-term ovariectomized), and their interaction. In addition, a comparison of the patterns of basal LH secretion between ovariectomized and ovariectomized oestradiol-treated hinds was made by analysis of variance of the concentrations obtained on each sampling occasion, and by comparing the areas under the curve between the peak in the first breeding season and the nadir during anoestrus and between the nadir and second breeding season. Patterns of LH concentrations during anoestrus were further analysed with regard to the time that peripheral plasma concentrations first fell below, or increased above, $0.2 \mathrm{ng} \mathrm{ml}^{-1}$ and remained at these values for two samples or more. In the analysis of the response to $\mathrm{GnRH}$, 
$\left.\begin{array}{l}2 \\ 1 \\ 0\end{array}\right]$

(a)
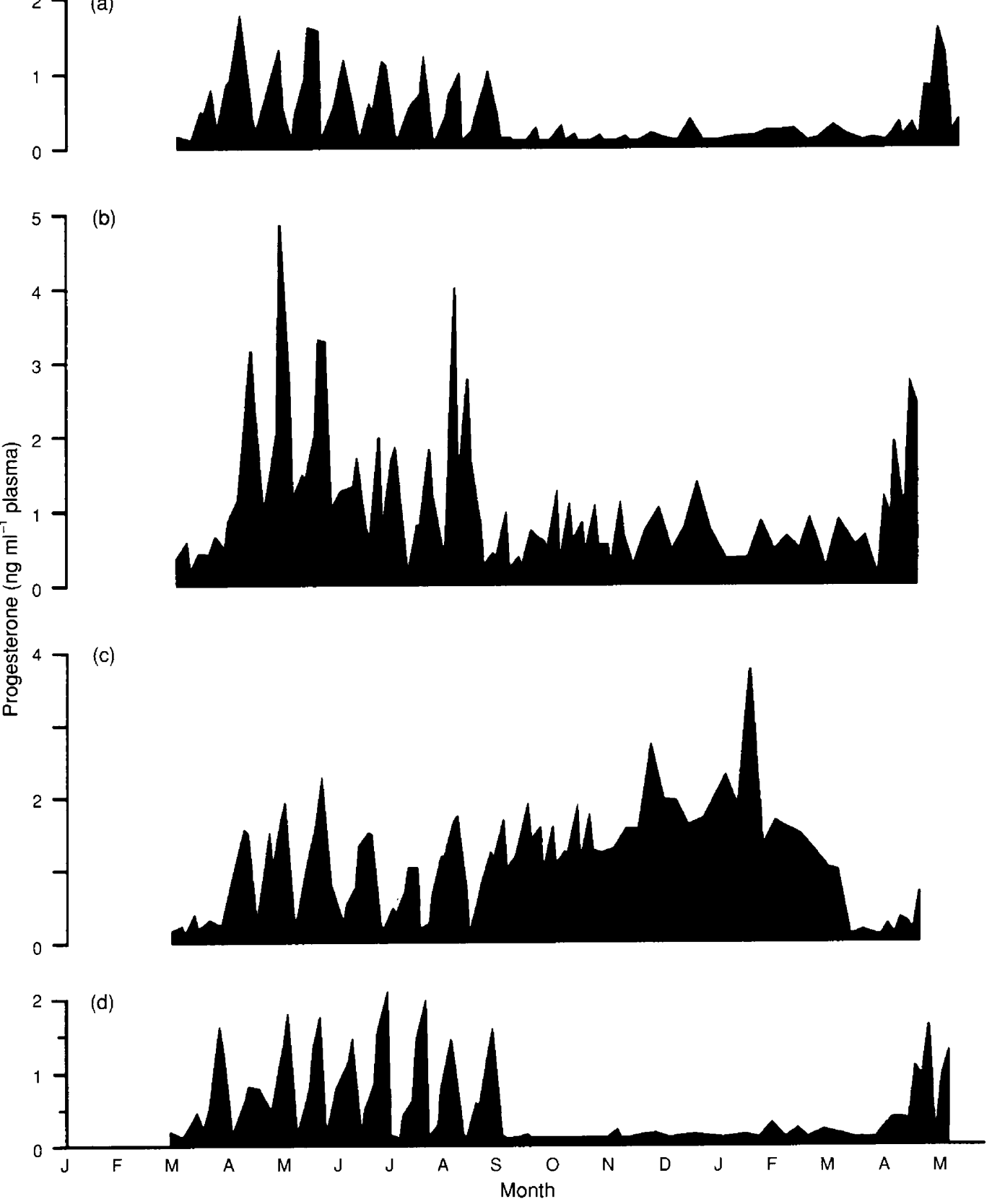

Fig. 1. Plasma progesterone profiles for four individual, intact, red deer hinds sampled once a week (non-breeding season) or twice a week (breeding season). (a) and (d) are representative of most (6 of 8 ) animals with the remaining two hinds (b) and (c) having patterns in which it was not possible to distinguish between breeding and non-breeding seasons.

baseline LH concentrations (time 0 ) were subtracted from the sample taken $15 \mathrm{~min}$ after $\mathrm{GnRH}$ treatment for each hind. All results are expressed as the mean and range or as the mean \pm SEM.

\section{Results}

Breeding and non-breeding seasons

The 1990 breeding season, during which six of eight hinds had seven to nine ovarian cycles, began at a mean date of
29 March \pm 1.4 days and ended on 4 September \pm 8.4 days (Fig. 1). Seasonal anoestrus had a mean duration of $202 \pm 16.8$ days. The 1991 breeding season began on 3 April \pm 9.0 days (although two hinds had not become cyclic before the end of sampling on 19 April).

\section{Seasonal plasma concentrations of $L H$}

One short-term ovariectomized, oestradiol-treated hind lost its implant during the experiment and was subsequently 
removed from analysis. Profiles of mean LH concentrations in ovariectomized hinds are shown (Fig. 2).

During the time of the breeding season (determined from the intact hinds) mean LH concentrations in ovariectomized oestradiol-treated hinds were 0.6 (range: $0.1-2.5) \mathrm{ng} \mathrm{ml}^{-1}$ plasma, gradually increasing from $0.3 \pm 0.09 \mathrm{ng} \mathrm{ml}^{-1}$ on 2 April to $1.1 \pm 0.16 \mathrm{ng} \mathrm{ml}^{-1}$ on 29 May and then decreasing to $0.2 \pm 0.07 \mathrm{ng} \mathrm{ml}^{-1}$ at the end of the breeding season on 3 September. In contrast, the non-breeding season was characterized by significantly $(P<0.001)$ lower mean LH concentrations (mean 0.1 , range: $0-0.9 \mathrm{ng} \mathrm{ml}^{-1}$ plasma).

In ovariectomized hinds that did not receive oestradiol treatment, mean $\mathrm{LH}$ concentrations also displayed a seasonal pattern, being highest during the breeding season, peaking at $1.1 \mathrm{ng} \mathrm{ml} \mathrm{m}^{-1}$ on 18 June, and reaching lowest values during the non-breeding season, $0.1 \mathrm{ng} \mathrm{ml}^{-1}$ on 26 November (Fig. 2). Concentrations recorded at these seasonal peaks and nadirs were similar to those recorded in the ovariectomized oestradiol-treated hinds and the nadir was also similar to concentrations recorded in the intact hinds. However, although peak and trough values were similar, LH concentrations in the ovariectomized hinds decreased from peak values more slowly and increased earlier compared with ovariectomized oestradioltreated hinds. This was evident in the significantly higher LH concentrations recorded in the ovariectomized hinds on nearly all occasions except for periods during the breeding season, and around November when concentrations were at their lowest in all animals, and was also apparent when analysed as the area under the curve between the first breeding season peak and the anoestrous nadir $(P<0.01)$ and the nadir to the second breeding season $(P<0.001)$. This gradual change in LH concentrations in ovariectomized hinds occurred throughout the study (Fig. 2), and was inversely proportional to and about 4 weeks in advance of the prevailing photoperiod (LH concentration $=1.84-0.0991$ daily photoperiod; $r^{2}=0.62$; $P<0.001$ ).

Ovariectomized hinds had higher mean LH concentrations than did ovariectomized, oestradiol-treated hinds during both the breeding $(0.9$, range $0.3-2.8$ versus 0.6 , range $0.1-$ $2.5 \mathrm{ng} \mathrm{ml}^{-1}$, respectively; $\left.P<0.01\right)$ and non-breeding $(0.5$, range $0.1-2.3$ versus 0.1 , range $0-0.9 \mathrm{ng} \mathrm{ml}^{-1}$, respectively; $P<0.001$ ) seasons.

Plasma LH concentrations in intact hinds generally remained below $0.2 \mathrm{ng} \mathrm{ml}^{-1}$. However, concentrations of $1.5-$ $5.0 \mathrm{ng} \mathrm{ml}{ }^{-1}$ were recorded on seven occasions within the breeding season in four animals, and were accompanied by behavioural oestrus on three occasions. Apart from this, there was no evidence of any seasonal patterns in LH secretion.

\section{Seasonal pituitary $L H$ response to $G n R H$}

The $\mathrm{LH}$ response to exogenous $\mathrm{GnRH}$ given at intervals of 4 weeks are presented (Fig. 2). Between April and August (breeding season) the mean $\mathrm{LH}$ concentration for ovariectomized hinds treated with oestradiol averaged 16.4 (range: $1.4-32.3) \mathrm{ng} \mathrm{ml}^{-1}$, significantly greater than that recorded in ovariectomized hinds without oestradiol treatment (mean 7.4, range: $1.2-14.6 \mathrm{ng} \mathrm{ml}^{-1} ; P<0.001$ ). Mean $\mathrm{LH}$ concentrations in ovariectomized, oestradiol-treated hinds decreased rapidly over September to November, averaging 3.1 (range 0.2-14.0) $\mathrm{ng} \mathrm{ml} \mathrm{ml}^{-1}$ over the non-breeding season. In contrast, the decrease in mean LH response at this time in untreated ovariectomized hinds was of a much lower magnitude, with concentrations averaging 4.2 (range $0.8-12.8) \mathrm{ng} \mathrm{ml}^{-1}$ during the non-breeding season, significantly $(P<0.001)$ greater than that of oestradiol-treated hinds.

The $\mathrm{LH}$ response to $\mathrm{GnRH}$ treatment in the intact hinds was of a much lower magnitude than that in either group of ovariectomized hinds, averaging just 1.0 (range: $0.2-2.3$ ) and 1.3 (range: $0-5.7) \mathrm{ng} \mathrm{ml}^{-1}$ during the breeding and nonbreeding season, respectively. A marked decline in responsiveness was noted (Fig. 2) during part of anoestrus and was at a minimum in November (mean 0.2, range: $0-0.3 \mathrm{ng} \mathrm{ml}^{-1}$ ).

\section{Effect of history of ovarian removal}

Essentially similar patterns of LH secretion were measured in those hinds ovariectomized at the beginning of the experiment, compared with those ovariectomized 2.3 years earlier. However, LH concentrations were slightly greater in those animals ovariectomized for the longer period (Table 1). Similarly, the nadir (mean concentrations $<0.2 \mathrm{ng} \mathrm{ml}^{-1}$ plasma) in $\mathrm{LH}$ concentrations recorded during anoestrus was reached significantly earlier in the short-term compared with long-term ovariectomized hinds (29.2 days earlier in ovariectomized, oestradiol-treated hinds, $P<0.05$; and 21.3 days earlier in ovariectomized, untreated hinds, $P<0.05$ ). The subsequent increase in LH concentrations occurred at similar times in both long-term and short-term ovariectomized hinds. The interaction between oestradiol treatment and history of ovarian removal was significant $(P<0.05)$ in only one instance, that of basal $\mathrm{LH}$ secretion during the breeding season.

\section{Discussion}

An important finding of the study reported here was the marked seasonal variation in the ability of exogenous oestradiol to suppress tonic LH concentrations in ovariectomized hinds. The breeding season was characterized by minimal suppression and anoestrus by maximal suppression; these changes were approximately aligned with the onset and cessation of ovarian activity recorded in intact herdmates. This is in agreement with previous work in sheep (Legan et al., 1977; Goodman et al., 1982; Webster and Haresign, 1983) and goats (Henniawati et al, 1995), indicating that a change in the steroid-feedback mechanism determines, or at least accompanies, changes in reproductive status. However, the present study also revealed that two other mechanisms may be important in regulating seasonality. The first, a steroidindependent mechanism, is suggested by the marked circannual pattern in $\mathrm{LH}$ secretion in ovariectomized hinds that did not receive oestradiol. This was even apparent 2.3-3.5 years after ovariectomy. This pattern has also been noted in ovariectomized hares (Davis and Meyer, 1973; Calliol et al, 1990) and mares (Garcia and Ginther, 1976; Freedman et al., 1979) as well as in ewes, in which it is evident as a change in the frequency of episodic LH secretion (Goodman et al., 1982; Robinson et al., 1985). A similar pattern, although somewhat equivocal, has Downloaded from Bioscientifica.com at 04/26/2023 11:25:20AM 
1

(a)
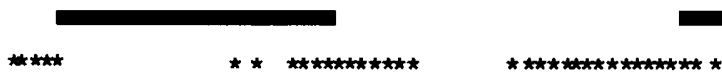

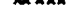

(b)

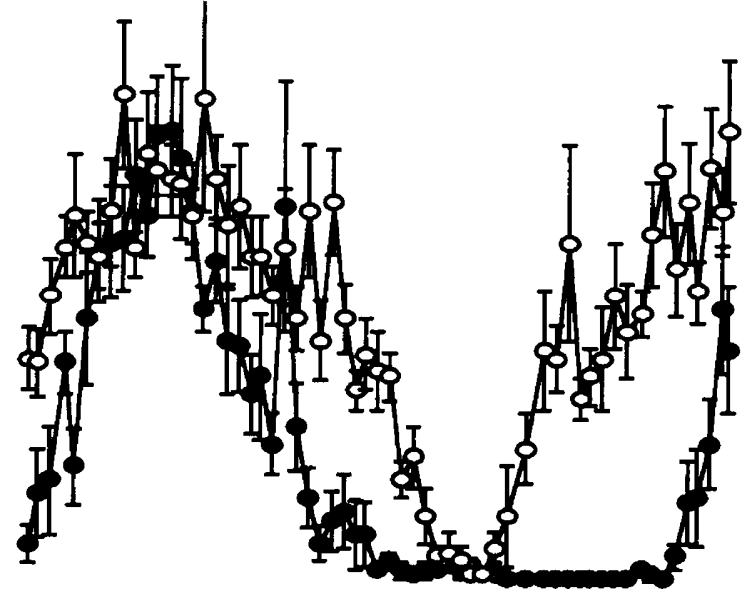

\begin{tabular}{l} 
을 \\
$\frac{\pi}{2}$ \\
$\frac{\pi}{2}$ \\
\hline \\
\hline \\
\hline
\end{tabular}

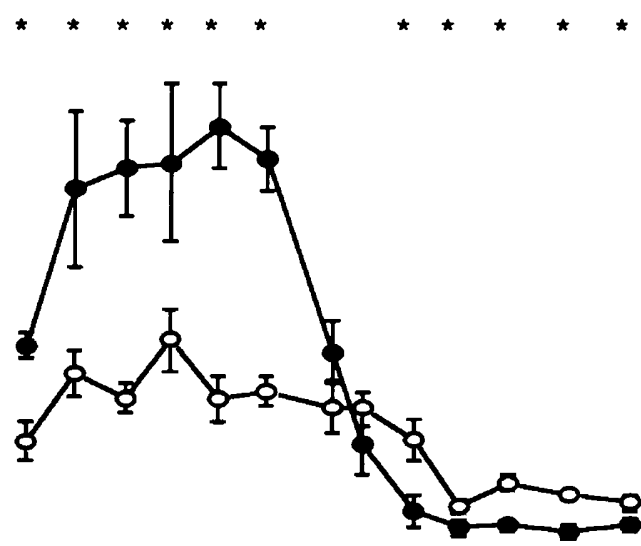

37 (c)

(c)

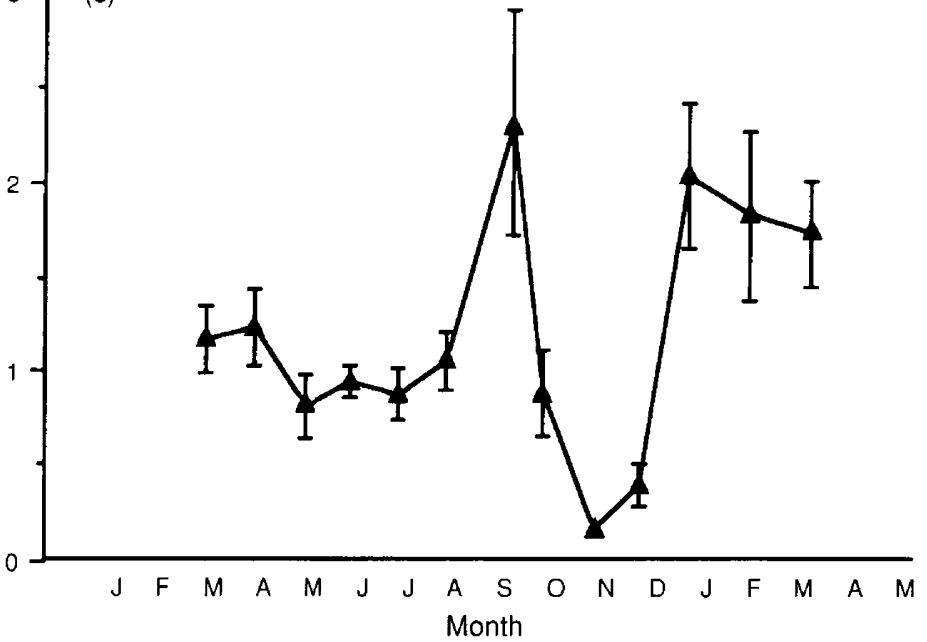

Fig. 2. Mean ( \pm SEM) concentrations of (a) seasonal plasma LH and (b) GnRHinduced $\mathrm{LH}$, in $(\mathrm{O})$ ovariectomized and $(0)$ ovariectomized and oestradiol-treated hinds, and (c) $\mathrm{GnRH}$-induced LH concentrations in intact hinds. $\mathrm{LH}$ concentrations were determined from blood samples taken approximately once a week, while the response to $\mathrm{GnRH}$, determined by subtracting the time zero concentration from that obtained $15 \mathrm{~min}$ after i.v. administration of $10 \mu \mathrm{g} \mathrm{GnRH}$, was determined at intervals of approximately 4 weeks. The horizontal bars represent the mean breeding season determined by monitoring progesterone secretion in the intact hinds. The asterisks indicate significant differences (at leastnPoßd0.05) r between iovarifica.com at 04/26/2023 11:25:20AM ectomized and ovariectomized oestradiol-treated hinds at each sampling occasion. 
Table 1. The effect of time from ovariectomy until the beginning of the experiment on plasma LH concentrations in oestradiol-treated and untreated ovariectomized red deer hinds during the breeding and non-breeding seasons.

\begin{tabular}{|c|c|c|c|}
\hline \multirow[b]{2}{*}{ Group } & \multicolumn{3}{|c|}{ Mean (range) $\mathrm{LH}$ secretion (ng $\mathrm{ml}^{-1}$ plasma) } \\
\hline & $\begin{array}{c}\text { Short-term } \\
\text { ovariectomized } \\
\text { (1 week) }\end{array}$ & $\begin{array}{l}\text { Long-term } \\
\text { ovariectomized } \\
(2.3 \text { years })\end{array}$ & $\begin{array}{c}\text { Significance } \\
\text { of contrast between } \\
\text { short- and long-term } \\
\text { ovariectomized }^{\dagger}\end{array}$ \\
\hline \multicolumn{4}{|l|}{ Basal LH secretion } \\
\hline \multicolumn{4}{|l|}{ Ovariectomized } \\
\hline Breeding season & $0.8(0.3-1.6)$ & $0.9(0.4-2.8)$ & NS \\
\hline Anoestrus & $0.4(0.1-1.2)$ & $0.5(0.1-2.3)$ & NS \\
\hline \multicolumn{4}{|c|}{ Ovariectomized + oestradiol treated } \\
\hline Breeding season & $0.4(0.1-1.7)$ & $0.7(0.1-2.5)$ & $* * *$ \\
\hline Anoestrus & $0.1(0.1-0.6)$ & $0.1(0.0-0.9)$ & NS \\
\hline \multicolumn{4}{|c|}{ GnRH-induced LH secretion } \\
\hline \multicolumn{4}{|l|}{ Ovariectomized } \\
\hline Breeding season & $6.6(2.9-12.5)$ & $8.2(1.2-14.6)$ & NS \\
\hline Anoestrus & $3.3(0.8-9.2)$ & $5.1(2.1-12.8)$ & $*$ \\
\hline \multicolumn{4}{|c|}{ Ovariectomized + oestradiol treated } \\
\hline Breeding season & $16.8(7.3-32.3)$ & $16.1(1.4-27.6)$ & NS \\
\hline Anoestrus & $2.0(0.2-11.0)$ & $4.0(0.8-14.0)$ & $* * *$ \\
\hline
\end{tabular}

${ }^{\dagger} \mathrm{NS}=$ not significant; $* P<0.05 ; * * P<0.001$.

been reported in castrated male deer (red, Lincoln and Kay, 1979; McMahon, 1994; white-tailed, Bubenik et al., 1982). The second methanism is suggested by the seasonal variation in pituitary responsiveness to exogenous $\mathrm{GnRH}$, seen in both untreated and oestradiol-treated ovariectomized hinds, and in intact hinds. This has also been reported in red deer stags (Suttie et al., 1984; Fennessy et al., 1988). Although this variation is also steroid independent, its magnitude is clearly modified by oestradiol. Separate studies in ovariectomized deer have shown a period of seasonal quiescence in the positive feedback effects of oestradiol (Meikle and Fisher, 1990; Jabbour et al., 1992). Collectively, these results would suggest that seasonal influences act on several components of the hypothalamic-pituitary-ovarian axis and, although likely to be driven by a central neuroendocrine mechanism, the contribution of all mechanisms to seasonality, albeit in a passive or subordinate manner, should not be overlooked. For instance, the change in pituitary responsiveness to exogenous $\mathrm{GnRH}$, thought to be of relatively little importance in regulating ovarian function in ewes (McLeod et al., 1982), is a function of releasable LH which in turn is inversely related to the frequency of endogenous GnRH secretion (Clarke and Cummins, 1985; Clarke et al., 1987). However, in hinds, the greatest response to exogenous $\mathrm{GnRH}$ occurs during the breeding season when the frequency of endogenous GnRH would be expected to be maximum, at least as determined by more frequent pulsatile LH secretion in these animals (L. M. Meikle and $\mathrm{M}$. W. Fisher, unpublished data). This probably reflects differences between physiological amounts of $\mathrm{GnRH}$ and the $10 \mu \mathrm{g}$ pharmacological dose used in the present study (chosen so that the possible confounding influences of coincident endogenous $\mathrm{GnRH}$ would be minimized).
Since both steroid-dependent and -independent mechanisms are evident and since present experimental techniques cannot differentiate between the mechanisms, the contention that steroid-dependent regulation is the major determinant of seasonality (Karsch et al., 1993) remains unconvincing. As both mechanisms may be mediated via different neural systems (Pau and Jackson, 1985; Meyer and Goodman, 1986; Goodman, 1988), it is possible that they both interact in the regulation of seasonality (Robinson et al., 1985). Futhermore, the effects of season on basal and GnRH-induced LH secretion in the present study suggest that the real central physiological control mechanism is steroid independent, its effects merely amplified, both in magnitude and temporally, by the presence of oestradiol (steroid-dependent), as Lincoln and Short (1980) suggested. Animals with quiescent or regressed gonads during anoestrus do not immediately show a gonadotrophin response to castration (Lincoln and Short, 1980) indicating that a steroid-dependent mechanism is not fully competent at all times, and that some other mechanism inhibits or prevents LH secretion. Further evidence for steroid-independent regulation may be the differing depths or stages of anoestrus noted in sheep (McNeilly et al., 1985) and deer. For instance, in the present study the intact hinds displayed a marked reduction in the $\mathrm{LH}$ response to exogenous $\mathrm{GnRH}$ in the early compared with the later part of anoestrus, a pattern also noted in ovary-intact Père David's deer (Curlewis et al., 1991; McLeod et al., 1991). These results suggest that anoestrus is not a uniform state but is characterized by an early 'deep' period (Curlewis et al., 1991) and a steroid-independent mechanism is the most likely explanation.

All the steroid-independent, as well as the steroiddependent, seasonal alterations in $\mathrm{LH}$ concentrations observed 
in hinds in the present study are also evident in at least some breeds of ewe, albeit at a significantly reduced magnitude. Since domestication can reduce the amplitude of seasonal reproductive parameters (see Setchell, 1992), the differences between the hind and ewe may merely indicate the extent to which they have been domesticated, or reflect the degree of gonadal regression that occurs during the non-breeding season (Goodman and Karsch, 1981). It will be interesting to see if farming and domestication modifies reproductive seasonality in deer, and indeed this animal provides an almost unique opportunity to monitor the effects of domestication in an ungulate (Fisher and Bryant, 1993).

The use of a relatively recently domesticated experimental animal, such as the deer, also imposes some other limitations upon interpretation of the data. These animals are not as docile as the domestic ewe, and the acts of yarding, handling and blood sampling may possibly affect hormone secretion. For instance, progesterone secretion throughout anoestrus recorded in two hinds may have been of adrenal origin (Jopson et al., 1990) or alternatively might reflect persistent luteal activity (Curlewis et al., 1988; Brinklow et al., 1992). However, although these limitations should be taken into consideration it is unlikely that they would affect the major conclusions reached in this study.

The duration of the interval between ovariectomy and the start of the experiment had little effect on the results, apart from altering the magnitude of the seasonal alterations in $\mathrm{LH}$ secretion as might be expected given the longer steroid-free environment and probable differences in metabolic clearance rates (Montgomery et al., 1984). Since the seasonal patterns of LH secretion were similar in both groups of hinds, the inclusion of animals of varied experimental histories in seasonality experiments ensures the interpretation of seasonal patterns is not unduly confounded by time after ovariectomy (Montgomery et al., 1985).

The authors are indebted to the many people at Invermay who have made significant contributions to this study, especially P. F. Fennessy, P. D. Johnstone, R. P. Littlejohn, C. G. Mackintosh, B. J. McLeod, T. R. Manley, G. H. Shackell, J. M. Suttie and A. J. Whaanga. They also thank Y. Combarnous, INRA, Nouzilly, France and A. F. Parlow, National Institute of Diabetes and Digestive and Kidney Diseases, Bethesda, USA for the generous provision of assay reagents.

\section{References}

Brinklow BR, Mcleod BJ, Loudon ASI and Curlewis JD (1992) Induction of ovulation in Père David's deer hinds at two stages of seasonal anestrus. In The Biology of Deer pp 320-326 Ed. RD Brown. Springer-Verlag, New York Bubenik GA, Morris JM, Schams D and Claus A (1982) Photoperiodicity and circannual levels of $\mathrm{LH}, \mathrm{FSH}$, and testosterone in normal and castrated male, white-tailed deer. Canadian Journal of Physiology and Pharmacology 60 788-793

Caillol M, Modain-Monval M, Meunier M and McNeilly AS (1990) Effect of ovariectomy at two periods of the year on LH and FSH basal concentrations and pituitary response to LHRH in the brown hare (Lepus europaeus) Journal of Reproduction and Fertility $\mathbf{8 8} 533-542$

Clarke IJ and Cummins IT (1985) GnRH pulse frequency determines LH pulse amplitude by altering the amount of releasable LH in the pituitary glands of ewes Journal of Reproduction and Ferility 73 425-431

Clarke IJ, Cummins JT, Crowder ME and Nett TM (1987) Pituitary receptors for gonadotropin-releasing hormone in relation to changes in pituitary and plasma luteinizing hormone in ovariectomized-hypothalamo-pituitary disconnected ewes. I. Effect of changing frequency of gonadotropin-releasing hormone pulses Biology of Reproduction 37 749-754

Curlewis JD, Loudon ASI and Coleman APM (1988) Oestrous cycles and the breeding season of the Père David's deer hind (Elaphurus davidianus) Journal of Reproduction and Fertility 82 119-126

Curlewis JD, McLeod BJ and Loudon ASI (1991) LH secretion and response to $\mathrm{GnRH}$ during seasonal anoestrus of the Père David's deer hind (Elaphurus davidianus) Journal of Reproduction and Fertility 91 131-138

Davis GJ and Meyer RK (1973) Seasonal variation in LH and FSH of bilaterally castrated snowshoe hares General and Comparative Endocrinology 20 61-68

Fennessy PF, Suttie JM, Crosbie SF, Corson ID, Elgar HJ and Lapwood KR (1988) Plasma LH and testosterone responses to gonadotrophin-releasing hormone in adult red deer (Cerous elaphus) stags during the annual antler cycle Journal of Endocrinology 117 35-4I

Fisher MW and Bryant LD (1993) What might be the consequences of adapting wild animals such as wapiti to a farm environment? Proceedings of the New Zealand Society of Animal Production 53 457-460

Freedman LJ, Garcia MC and Ginther OJ (1979) Influence of photoperiod and ovaries on seasonal reproductive activity in mares Biology of Reproduction 20 $567-574$

Garcia MC and Ginther OJ (1976) Effects of ovariectomy and season on plasma luteinizing hormone in mares Endocrinology 98 958-962

Goodman RL (1988) Neuroendocrine control of the ovine estrous cycle. In The Physiology of Reproduction pp 1929-1969 Eds E Knobil and J Neill. Raven Press, New York

Goodman RL and Karsch FJ (1981) A critique of the evidence on the importance of steroid feedback to seasonal changes in gonadotrophin secretion. Journal of Reproduction and Fertility Supplement 30 1-13

Goodman RL, Legan SJ, Ryan KD, Foster DL and Karsch FJ (1981) Importance of variations in behavioural and feedback actions of oestradiol to the control of seasonal breeding in the ewe Journal of Endocrinology $89229-240$

Goodman RL, Bittman EL, Foster DL and Karsch FJ (1982) Alterations in the control of luteinizing hormone pulse frequency underlie the seasonal variation in estradiol negative feedback in the ewe Biology of Reproduction 27 $580-589$

Haresign W and Friman BR (1983) Response of ovariectomized ewes to injection of oestradiol-17 $\beta$ at different times of the year Journal of Reproducfion and Fertility $69469-472$

Henniawati, Restall BJ and Scaramuzzi RJ (1995) Effect of season on LH secretion in ovariectomized Australian cashmere does Journal of Reproduction and Fertility 103 349-356

Howland BE, Palmer WM, Sanford LM and Beaton DB (1978) Estrogen-induced LH and FSH release in ovariectomized ewes: effect of season Canadian Journal of Animal Science 58 547-55I

Jabbour HN, Asher GW, Smith JF and Morrow CJ (1992) Effect of progesterone and oestradiol benzoate on oestrous behaviour and secretion on luteinizing hormone in ovariectomized fallow deer (Dama dama) Journal of Reproduction and Fertility 94 353-361

Jopson NB, Fisher MW and Suttie JM (1990) Plasma progesterone concentrations in cycling and in ovariectomised red deer hinds: the effect of progesterone supplementation and adrenal stimulation Animal Reproduction Science 23 61-73

Joseph IBJK, Currie WD and Rawlings NC (1992) Effects of time after ovariectomy, season and oestradiol on luteinizing hormone and follicle-stimulating hormone secretion in ovariectomized ewes Journal of Reproduction and Fertility $94 \quad 511-523$

Karsch FJ, Dierschke DJ, Weick RF, Yamaji T, Hotchkiss J and Knobil E (1973) Positive and negative feedback control by estrogen of luteinizing hormone secretion in the rhesus monkey Endocrinology 92 799-804

Karsch FJ, Bittman EL, Foster DL, Goodman RL, Legan SJ and Robinson JE (1984) Neuroendocrine basis of seasonal reproduction Recent Progress in Hormone Research 40 185-232

Karsch FJ, Dahl GE, Evans NP, Manning JM, Mayfield KP, Moenter SM and Foster DL (1993) Seasonal changes in gonadotropin-releasing hormone secretion in the ewe: alteration in response to the negative feedback action of estradiol Biology of Reproduction 49 1377-1383

Land RB, Wheeler AG and Carr WR (1976) Seasonal variation in the oestrogen induced LH discharge of ovariectomized Finnish Landrace and Scottish Blackface ewes Annales de Biologie Animale, Biochimie Biophysique 16 $521-528$ 
Legan SJ, Karsch FJ and Foster DL (1977) The endocrine control of seasonal reproductive function in the ewe: a marked change in response to the negative feedback action of estradiol on luteinizing hormone secretion Endocrinology $101818-824$

Lincoln GA and Kay RNB (1979) Effects of season on the secretion of LH and testosterone in intact and castrated red deer stags (Cervus elaphus) Journal of Reproduction and Fertility 55 75-80

Lincoln GA and Short RV (1980) Seasonal breeding: nature's contraceptive Recent Progress in Hormone Research 36 1-52

Mackintosh CG and Van Reenen G (1984) Comparison of yohimbine, 4 aminopyridine and doxapram antagonism of xylazine sedation in deer (Cervus elaphus) New Zealand Veterinary Journal 32 181-184

McLeod BJ, Haresign W and Lamming GE (1982) Response of seasonally anoestrous ewes to small-dose multiple injections of $\mathrm{Gn}-\mathrm{RH}$ with and without progesterone pretreatment Journal of Reproduction and Fertility 65 223-230

McLeod BJ, Brinklow BR, Curlewis JD and Loudon ASI (1991) Efficacy of intermittent or continuous administration of $\mathrm{GnRH}$ in inducing ovulation in early and late seasonal anoestrus in the Père David's deer hind (Elaphurus davidianus) Journal of Reproduction and Fertility 91 229-238

McMahon CD (1994) Regulation of the Seasonal Pattern of Appetite and Growth in Red Deer Stags (Cervus elaphus). PhD thesis, University of Otago

McNeilly AS, Wallace JM and Baird DT (1985) Induction of ovulation in anoestrous ewes using gonadotrophins. In Endocrine Causes of Seasonal and Lactational Anoestrus pp 66-75 Eds F Ellendorf and F Elsaesser. Martinus Nijhoff, Dordrecht

Meikle LM and Fisher MW (1990) Induction of oestrus in the ovariectomised red deer with exogenous progesterone and oestradiol benzoate Proceedings of the New Zealand Society of Animal Production 50 155-159
Meyer SL and Goodman RL (1986) Separate neural systems mediate steroiddependent and steroid-independent suppression of tonic luteinizing hormone secretion in the anestrous ewe Biology of Reproduction 35 562-571

Montgomery GW, Crosbie SF, Martin GB and Pelletier J (1984) Changes in the clearance rate of immunoreactive LH after ovariectomy in Ile-de-France ewes. In Reproduction in Sheep pp 23-25 Eds DR Lindsay and DT Pearce. Australian Academy of Science and Australian Wool Corporation, Canberra

Montgomery GW, Martin GB and Pelletier J (1985) Changes in pulsatile LH secretion after ovariectomy in Ile-de-France ewes in two seasons Journal of Reproduction and Fertility 73 173-183

Pau K-YF and Jackson GL (1985) Effect of frontal hypothalamic deafferentation on photoperiod-induced changes of luteinizing hormone secretion in the ewe Neuroendocrinology 41 72-78

Robinson JE, Radford HM and Karsch FJ (1985) Seasonal changes in pulsatile luteinizing hormone $(\mathrm{LH})$ secretion in the ewe: relationship of frequency of LH pulses to day length and response to estradiol negative feedback Biology of Reproduction 33 324-334

Setchell BP (1992) Domestication and reproduction Animal Reproduction Science 28 195-202

Suttie JM, Lincoln GA and Kay RNB (1984) Endocrine control of antler growth in red deer stags Journal of Reproduction and Fertility 71 7-15

Thomas GB, Pearce DT, Oldham CM, Martin GB and Lindsay DR (1988) Effects of breed, ovarian steroids and season on the pulsatile secretion of $\mathrm{LH}$ in ovariectomized ewes Journal of Reproduction and Fertility 84 313-324

Webster GM and Haresign W (1983) Seasonal changes in LH and prolactin concentrations in ewes of two breeds Journal of Reproduction and Fertility 67 $465-471$ 